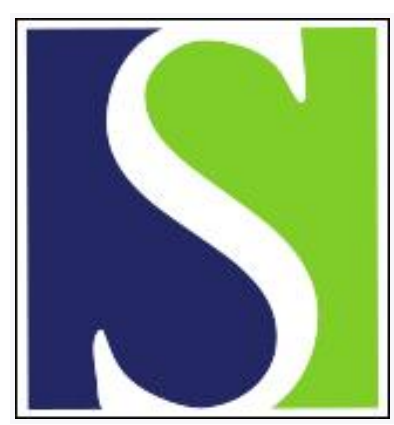

Scand J Work Environ Health 1992;18(6):346-350

https://doi.org/10.5271/sjweh.1563

Issue date: 01 Dec 1992

Fetal growth, preterm birth and infant mortality in relation to work with video display terminals during pregnancy.

by Nielsen CV, Brandt LP

Affiliation: Institute of Epidemiology and Social Medicine, University of Aarhus, Denmark.

This article in PubMed: www.ncbi.nlm.nih.gov/pubmed/1485159

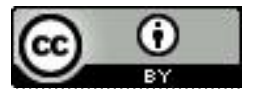




\title{
Fetal growth, preterm birth and infant mortality in relation to work with video display terminals during pregnancy
}

\author{
by Claus V Nielsen, MD, ${ }^{1,2}$ Lars PA Brandt, MD ${ }^{1,2}$
}

\begin{abstract}
NIELSEN CV, BRANDT LPA. Fetal growth, preterm birth and infant mortality in relation to work with video display terminals during pregnancy. Scand $J$ Work Environ Health 1992;18:346-350. Through register linkage between a trade union file and public health registers 24352 pregnancy outcomes were selected from a source population of 214108 commercial and clerical employees. In a case-base study including all recorded cases and a randomly selected base sample, the potential effect of video display terminal (VDT) use in pregnancy on the risk of low birthweight, preterm birth, light weight for delivery date, stillborn, perinatal death, and infant death was investigated. Data on VDT use and potential confounders were collected from postal questionnaires sent to 6312 women and 426 employers. The rate ratio for women exposed to any degree of use was 0.88 for low birthweight [ $95 \%$ confidence interval $(95 \% \mathrm{CI}) 0.67-1.16$ ], 1.11 for preterm birth $(95 \%$ CI $0.87-1.47), 0.99$ for light weight for delivery date $(95 \%$ CI $0.80-1.21)$, 0.73 for stillborn $(95 \% \mathrm{Cr} 0.36-1.48), 1.10$ for perinatal death $(95 \% \mathrm{CI} 0.62-1.94)$, and 0.20 for infant death $(95 \% \mathrm{CI} 0.04-1.03)$. In conclusion, this investigation did not show an increased risk of the studied adverse pregnancy outcomes among women with VDT use.
\end{abstract}

Key terms: case-base study, Denmark, recall bias, selection bias, reproductive failures.

The occurrence of adverse pregnancy outcomes among women working with a video display terminal (VDT) has been investigated in several studies (1-9). Those involving low birthweight $(2-5)$, preterm birth $(4,5)$, and infant mortality $(2,3,5)$ have not shown any harmful effect of VDT work on pregnancy outcome. The present study is part of a larger investigation initiated by the Union of Commercial and Clerical Employees in Denmark. The purpose was to estimate the risk of adverse pregnancy outcome among union members working with a VDT during pregnancy. This study focused upon light weight for delivery date, preterm birth, low birthweight, and infant mortality (ie, stillbirth, perinatal death, and infant death).

We have previously published results from case-base studies of the effect of VDT work during pregnancy on the risk of medically verified spontaneous abortion (8) and congenital malformations (9). No elevated risk from these two adverse pregnancy outcomes was found for VDT workers in comparison with non-VDT workers.

\footnotetext{
1 The Institute of Epidemiology and Social Medicine, University of Aarhus, Aarhus, Denmark.

2 Department of Occupational Medicine, Municipal Hospital of Aarhus, Aarhus, Denmark.
}

Reprint requests to: Dr CV Nielsen, The Institute of Epidemiology and Social Medicine, University of Aarhus, HoeghGuldbergsgade 8, DK-8000 Aarhus C, Denmark.

\section{Subjects and methods}

\section{Selection of subjects and information}

The investigation was conducted as a case-base study within a cohort (10). The source population included women who were members of the Union of Commercial and Clerical Employees for at least one month from 1982 to 1985 and who, at that time, were between 15 to 44 years of age. A total of 214108 women fulfilled these criteria. This trade union includes approximately $80 \%$ of all Danish women employed in commercial or clerical jobs (ie, various job categories in retail, wholesale, production, and service). All of the women were registered by their personal identification number in a trade union register. In Denmark this number is the main key for identification in all registers, including public health registers.

The population experience consisted of all births and diagnosed spontaneous abortions in the source population, with the exception of twins, triplets, and induced abortions. Information on births was obtained by register linkage of the Medical Birth Register and the women's personal identification numbers during the two-year follow-up period from 1 January 1984 to 31 December 1985. The Medical Birth Register includes birth certificates of more than $95 \%$ of all births in Denmark. Linkage of the union file register with the National Register of In-Patients provided information on diagnosed spontaneous abortions during the two years of follow-up from 1 July 1983 to 31 July 1985 (8). The results of studies on the risk of spontaneous abortion and congenital malformations related to VDT use have been published previously $(8,9)$. 
A total of 24352 pregnancy outcomes was recorded in the two-year follow-up period. Table 1 shows the numbers of all registered cases in the six case groups included in the present study. A base sample (reference group) of 2252 pregnancies $(9.2 \%$ ) was drawn randomly from all of the recorded pregnancies. The employers of women using a VDT at any time during their pregnancy were identified by register linkage of the case and base-sample groups with the Labour Market Supplementary Pension Fund.

\section{Assessment of exposure}

A questionnaire was sent in September 1987 to women in the case and the base-sample groups. Information on occupational status, job title, job stress, ergonomic work load, exposure to organic solvents, VDT use, and life-style factors (eg, alcohol consumption, smoking, and general state of health) was requested for every pregnancy in the follow-up period. The question concerning number of hours of VDT work during pregnancy was: "How many hours (average per week) did you work with a VDT during pregnancy?"

The response rates were $75.4 \%(\mathrm{~N}=1699$ pregnancies ) for the base sample, $73.9 \%(\mathrm{~N}=434)$ for low birthweight, $74.7 \%(\mathrm{~N}=443)$ for preterm birth, $75.8 \%$ $(\mathrm{N}=749)$ for light weight for delivery date, and $76.6 \%$ $(\mathrm{N}=160)$ for infant mortality.

In an exploration of the possibility of selection bias due to nonresponse, a random sample (14.5\%) of nonrespondents from the base-sample and case groups was selected. Interviewers not knowing the outcome of the pregnancy interviewed the nonrespondents who had a telephone.

To check the possibility of recall bias, we requested consent from the pregnant women using a VDT during pregnancy to ask their employers about the extent of VDT use. A total of 507 of the 938 women gave their consent. A questionnaire with six questions concerning VDT use was sent to a random sample of 333 of the employers in March 1988. One question concerning hours of VDT work corresponded to the question given to the women. The response rate from the employers was $85.6 \%$.

\section{Analysis}

Bias induced by potential confounders was controlled. The classifications of the potential confounding variables used are shown in table 2 . We adjusted for potential bias if a variable was associated at a level of statistical significance of $5 \%$. This adjustment was accomplished by means of the Mantel-Haenszel stratified analysis modified to case-base studies by Greenland (11). In the base sample, $80.5 \%$ of the women were employed. Among those employed, $33.5 \%$ worked with a VDT. The proportion of VDT users in the subgroup of clerical and administrative employees was
$55.2 \%$. An analysis was performed for the group of all employees and the subgroup of clerical and administrative employees.

Table 1. Distribution of pregnancy outcomes in the source population of 214108 women and in a base sample of the source population observed over a period of two years. The population experience is given for the purpose of comparison.

\begin{tabular}{|c|c|c|c|c|}
\hline \multirow{2}{*}{ Pregnancy outcome } & \multicolumn{2}{|c|}{ Source population } & \multicolumn{2}{|c|}{ Base samplea } \\
\hline & $\mathbf{N}$ & $\%$ & $\mathrm{~N}$ & $\%$ \\
\hline $\begin{array}{l}\text { Singleton delivery } \\
\text { Low birthweight }{ }^{\mathrm{b}} \\
\text { Preterm birthc } \\
\text { Light weight for delivery date } \\
\text { Stillbirth } \\
\text { Perinatal death } \\
\text { Infant death } \\
\text { Spontaneous abortion } \\
\text { Congenital malformation } \\
\text { Extrauterine pregnancy } \\
\text { Unspecified abortion }\end{array}$ & $\begin{array}{r}21554 \\
587 \\
593 \\
988 \\
73 \\
79 \\
40 \\
2248 \\
661 \\
332 \\
228\end{array}$ & $\begin{array}{l}88.5 \\
2.4 \\
2.4 \\
4.1 \\
3.0 \times 10^{-3} \\
3.2 \times 10^{-3} \\
1.6 \times 10^{-3} \\
9.2 \\
2.7 \\
1.4 \\
0.1\end{array}$ & $\begin{array}{r}1976 \\
55 \\
50 \\
94 \\
5 \\
8 \\
4 \\
4 \\
225 \\
71 \\
38 \\
21\end{array}$ & $\begin{array}{l}87.7 \\
2.4 \\
2.2 \\
4.2 \\
2.2 \times 10^{-3} \\
3.6 \times 10^{-3} \\
1.8 \times 10^{-3} \\
10.0 \\
3.2 \\
1.7 \\
1.0\end{array}$ \\
\hline $\begin{array}{l}\text { Total number of registered } \\
\text { pregnancy outcomes }\end{array}$ & 24362 & . & 2252 & . \\
\hline
\end{tabular}

a The base sample is a $9.2 \%$ random sample of population experience. A pregnancy outcome in the base-sample group can appear in one or more case groups.

b $<2500 \mathrm{~g}$ and borne after week 35 of gestation.

c Borne before week 36 of gestation.

- Birthweight in the lowest fifth percentile for gestational age of each gender.

Table 2. Potential confounders controlled in the analyses.

\begin{tabular}{|c|c|}
\hline Variable & Classification \\
\hline Maternal age & $15-29$ years, $>29$ years \\
\hline Previous pregnancies & 0,1, and $>1$ \\
\hline Previous deliveries & 0,1 , and $>1$ \\
\hline Previous spontaneous abortions & 0,1 , and $>1$ \\
\hline Previous induced abortions & 0,1, and $>1$ \\
\hline Previous infant mortality & 0,1, and $>1$ \\
\hline Gender of child & Girl/boy \\
\hline Job stress factors & $\begin{array}{l}\text { Two-level stress index on basis of } 12 \\
\text { questions of job stressors }\end{array}$ \\
\hline Ergonomic work load & $\begin{array}{l}\text { Heavy lifting (yes/no); sitting more } \\
\text { than } 1 \mathrm{~h} \text { at a time during a workday } \\
\text { (yes/no); standing more than } 1 \mathrm{~h} \text { at a } \\
\text { time during a workday (yes/no); varia- } \\
\text { tion of work position during a workday } \\
\text { (yes/no); standing, sitting, moving } \\
(0-2,3-4,5-6 \text {, and }>6 \text { h/d); treat- } \\
\text { ment of cervicobracial disorders dur- } \\
\text { ing pregnancy (yes/no) }\end{array}$ \\
\hline Organic solvents exposure & Daily exposure at work (yes/no) \\
\hline Smoking & $\begin{array}{l}0,1-10,>10 \text { cigarettes/d during first, } \\
\text { second-third trimester }\end{array}$ \\
\hline Alcohol consumption & $\begin{array}{l}0,1-4,>5 \text { drinks/week during first, } \\
\text { second-third trimester; more than } 10 \\
\text { drinks on certain occasions during } \\
\text { first, second-third trimester (yes/no) }\end{array}$ \\
\hline Medication & $\begin{array}{l}\text { Regular consumption of medicine dur- } \\
\text { ing first, second-third trimester (yes/ } \\
\text { no) }\end{array}$ \\
\hline Infections & $\begin{array}{l}\text { During first, second-third trimester } \\
\text { (yes/no) }\end{array}$ \\
\hline Chronic diseases & $\begin{array}{l}\text { One year before pregnancy, diagnosed } \\
\text { by practitioner (yes } / \text { no) }\end{array}$ \\
\hline Part-time work & $<33$ h/week (yes no) \\
\hline Ending work during pregnancy & $\begin{array}{l}\text { Before eighth month of pregnancy } \\
\text { (yes/no) }\end{array}$ \\
\hline Caesarean operation & Yesino \\
\hline Medically induced birth & Yes/no \\
\hline
\end{tabular}




\section{Results}

The rate ratio of adverse pregnancy outcomes according to employment during pregnancy is shown in table 3 . No statistically significant differences were found between the rate ratios of the employed and unemployed.

Table 4 shows the crude rate ratios and the adjusted rate ratios after adjustment for potential confounders, and the $95 \%$ confidence intervals both for any VDT use during pregnancy compared with no VDT use during pregnancy and for VDT use for $<1,1-10$, $11-20,21-30$, and $>31 \mathrm{~h} /$ week during pregnancy compared with no VDT use during pregnancy. Because of the few number of cases among the VDT users the stratification according to hours per week had to be reduced for the variables stillborn and perinatal death and excluded for infant death. Although rate ratios greater than 1 occurred in more case groups both with respect to any versus no VDT use and hours per week versus no use, no statistical significance was found.

An analysis of the data on administrative and clerical employees supported the results by showing no effect of VDT use on the pregnancy outcomes involved in this study. One exception was found for preterm birth in relation to any VDT use with an adjusted rate ratio of 1.37 (95\% confidence interval $0.99-1.92)$.

\section{Discussion}

Although some women contributed with more than one pregnancy, all of the pregnancies were treated as independent events in our analysis. The average number of pregnancies per woman was low $(\mathrm{N}=1.05)$. We assumed therefore that treating them as independent events would have only a minor effect on the estimation and testing (12).

For recall bias to be responsible for the lack of association between VDT use and adverse pregnancy outcome, the women who experienced an adverse outcome must have underreported VDT exposure during pregnancy compared with the women in the base-sample group. Alternatively, the women in the base-sample group must have overreported their VDT exposure in comparison with the women in the case group.

There was a tendency for the women in all of the case groups and those in the base sample to overreport their VDT use when their responses were compared with the information given by their employers (table 5). However, a test for agreement between the differences in the statements by the women and those by the employers in the case groups and in the base sample by Mann-Whitney's U-rank sum test did not show any statistically significant disagreement.

Women who use a VDT and experience an adverse pregnancy outcome can be expected to be more willing to answer the questionnaires than women who give birth to a normal child. In order to study this potential selection bias, the distribution of VDT work in the random sample of nonrespondents was applied to the whole group of nonrespondents. By doing this, we could estimate the selection probabilities for each case group and the base sample according to any versus no VDT exposure. Finally, the selection odds ratio (OR) for each case group was calculated $(8,13)(1.14$ for low birthweight, 1.13 for preterm birth, 1.11 for light weight for delivery date, 0.92 for infant mortality).

The selection odds ratios indicated that selection bias due to nonrespondents produced a slight overestimation of the rate ratios, except for the case group of infant mortality. In conclusion, this study does not indicate an increased risk of the following adverse pregnancy outcomes: light weight for delivery date, preterm birth, low birthweight, and infant mortality for women using a VDT during pregnancy.

Extremely low-frequency electromagnetic fields have been investigated in several experimental studies on developing chicken and mouse embryos and human cells for a potential hazardous effect. No convincing and unambiguous association with reproductive failures has been found. This study was not designed to collect precise information of the magnetic fields of video display terminals. However, if it is assumed that (i) the terminals were distributed on the different strata of VDT work (hours per week) independently of the electromagnetic field strength and (ii) the average number of workhours with a VDT per week during pregnancy is used as an estimate of the level of electromagnetic field exposure during pregnancy, nothing in this study indicates that these extremely low-frequency electromagnetic fields cause adverse pregnancy outcomes.

It was not possible to study the risk of very early spontaneous abortions because these abortions are not medically verified and recorded in the health registers. Thus, except for very early spontaneous abortions $(8$,

Table 3. Prevalence and crude rate ratio for adverse pregnancy outcomes in the base sample according to employment.

\begin{tabular}{|c|c|c|c|c|c|c|}
\hline & \multicolumn{2}{|c|}{ Employed } & \multicolumn{2}{|c|}{ Unemployed } & \multirow{2}{*}{$\begin{array}{l}\text { Crude } \\
\text { rate } \\
\text { ratio }\end{array}$} & \multirow{2}{*}{$\begin{array}{c}95 \% \\
\text { confidence } \\
\text { interval }\end{array}$} \\
\hline & $\mathbf{N}$ & Prevalence & $\mathbf{N}$ & Prevalence & & \\
\hline $\begin{array}{l}\text { Deliveries } \\
\text { Low birthweight } \\
\text { Preterm birth } \\
\text { Light weight for delivery date } \\
\text { Infant mortality }\end{array}$ & $\begin{array}{r}1187 \\
37 \\
39 \\
62 \\
8\end{array}$ & $\begin{array}{r}30.2 \\
31.9 \\
50.7 \\
7.4\end{array}$ & $\begin{array}{r}302 \\
4 \\
6 \\
10 \\
1\end{array}$ & $\begin{array}{r}13.2 \\
19.9 \\
33.1 \\
3.3\end{array}$ & $\begin{array}{l}2.40 \\
1.68 \\
1.61 \\
2.04\end{array}$ & $\begin{array}{l}0.95-8.05 \\
0.76-4.44 \\
0.85-3.37 \\
0.37-37.96\end{array}$ \\
\hline
\end{tabular}


Table 4. Rate ratios for low birthweight, preterm birth, light for delivery date, stillbirth, perinatal death, and infant death according to work with a video display terminal (VDT) among gainfully employed women.

\begin{tabular}{|c|c|c|c|c|c|c|}
\hline \multirow{2}{*}{ VDT work } & \multicolumn{2}{|c|}{$\begin{array}{c}\text { Number of } \\
\text { pregnancies }\end{array}$} & \multirow{2}{*}{$\begin{array}{l}\text { Cases } \\
\text { in base } \\
\text { sample }\end{array}$} & \multirow{2}{*}{$\begin{array}{l}\text { Crude } \\
\text { rate } \\
\text { ratio }\end{array}$} & \multirow{2}{*}{$\begin{array}{l}\text { Adjusted } \\
\text { rate } \\
\text { ratio }\end{array}$} & \multirow{2}{*}{$\begin{array}{l}95 \% \text { confidence } \\
\text { interval of the } \\
\text { adjusted } \\
\text { rate ratio }\end{array}$} \\
\hline & $\begin{array}{l}\text { Case } \\
\text { group }\end{array}$ & $\begin{array}{l}\text { Base } \\
\text { sample }\end{array}$ & & & & \\
\hline
\end{tabular}

\section{Low birthweight}

None

Any

$237 \quad 909 \quad 28$

Average number of hours/week

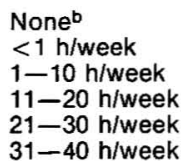

$\begin{array}{rr}238 & 923 \\ 9 & 35 \\ 43 & 221 \\ 22 & 93 \\ 21 & 61 \\ 13 & 32\end{array}$

11

0.93

0.88

$0.67-1.16$

Preterm birth

None

Any

236

126

909

456

1.11

$0.87-1.47$

Average number of hours/week

None ${ }^{\mathrm{b}}$
$<1 \mathrm{~h} / \mathrm{week}$
$1-10 \mathrm{~h} / \mathrm{week}$
$11-20 \mathrm{~h} /$ week
$21-30 \mathrm{~h} /$ week
$31-40 \mathrm{~h} /$ week

$\begin{array}{rr}241 & 923 \\ 12 & 35 \\ 62 & 221 \\ 23 & 93 \\ 10 & 61 \\ 14 & 32\end{array}$

24

2

1.31

1.07

1.00

0.75

0.92

1.34

1.58

0.92

0.86

0.86
1.06

1.34

$0.43-1.96$

$0.51-1.21$

$0.52-1.43$

$0.63-1.80$

$0.68-2.63$

Light weight for delivery date

None

Any

405

909

0.95

0.63

1.13

0.96

0.61

1.52

$0.60-2.58$

$0.82-1.56$

$0.59-1.56$

$0.30-1.22$

$0.73-3.12$

Average number of hours/week

None
$<1 \mathrm{~h} /$ week
$1-10 \mathrm{~h} /$ week
$11-20 \mathrm{~h} /$ week
$21-30 \mathrm{~h} /$ week
$31-40 \mathrm{~h} /$ week

$\begin{array}{rr}409 & 923 \\ 20 & 35 \\ 84 & 221 \\ 55 & 93 \\ 29 & 61 \\ 18 & 32\end{array}$

1.03

0.99

$0.80-1.21$

Stillbirth

None

Any

$\begin{array}{ll}37 & 909 \\ 14 & 456\end{array}$

0.86

1.14
0.91

1.23

0.85

1.07

1.00

$0.64-2.03$

$0.68-1.46$

$0.86-1.76$

$0.54-1.34$

$0.55-1.81$

Average number of hours/week

None ${ }^{b}$
$<1 \mathrm{~h} /$ week
$1-20 \mathrm{~h} /$ week
$21-40$ h/week

$\begin{array}{rr}37 & 923 \\ 4 & 93 \\ 9 & 314 \\ 1 & 35\end{array}$

0.75

0.73

$0.36-1.48$

Perinatal death

None

Any

$34 \quad 909$

$20 \quad 456$

909
456

$\begin{array}{rr}34 & 923 \\ 1 & 35 \\ 15 & 314 \\ 4 & 93\end{array}$

1.07

0.72

0.95

0.95
0.70

$0.45-2.03$

$\begin{array}{ll}- & 1.07 \\ - & 0.72 \\ & 0.7\end{array}$

0.82

$0.31-1.57$

$0.39-1.72$

Average number of hours/week
None ${ }^{b}$
$<1 \mathrm{~h} /$ week
$1-20 \mathrm{~h} /$ week
21-40 h/week

35
314
93

0.78

1.30

0.74

1.24

$\begin{array}{ll}- & 0.78 \\ - & 1.30 \\ & 1.17\end{array}$

0.95

$0.66-2.34$

Infant death

None

Any

$\begin{array}{rr}21 & 909 \\ 2 & 456\end{array}$

8
1

0.19

0.20

$0.04-1.03$

a With the Maentel Haenszel-stratified analysis (11) adjusted as follows: low birthweight: previous pregnancies, previous spontaneous and induced abortions, smoking, drinking, and serious drinking (more than 10 drinks on certain occasions) during second-third trimester, chronic diseases, Caesarian operation, and medically induced abortion; preterm birth: previous pregnancies, previous deliveries, previous spontaneous abortions, and gender of child; light weight for delivery date: previous pregnancies, previous deliveries, smoking, drinking, and serious drinking during second-third trimester, Caesarian operation, and medically induced birth; stillbirth, perinatal death and infant death: Caesarian operation and medically induced birth.

b Detailed information on hours of VDT-work per week was missing for some pregnancies. These pregnancies have been assigned a value of zero (none). 
Table 5. Cross-tabulation of the women's and employers' statements on the women's work with a video display terminal (VDT) during pregnancy.$^{\mathrm{a}}$

\begin{tabular}{|c|c|c|c|c|c|c|c|c|c|c|}
\hline \multirow{3}{*}{$\begin{array}{l}\text { Woman's } \\
\text { statement } \\
\text { (hours of } \\
\text { VDT work/week) }\end{array}$} & \multicolumn{10}{|c|}{ Employer's statement (hours of VDT work/week) } \\
\hline & \multicolumn{2}{|c|}{$0-1$} & \multicolumn{2}{|c|}{$1-10$} & \multicolumn{2}{|c|}{$11-20$} & \multicolumn{2}{|c|}{$21-30$} & \multicolumn{2}{|c|}{$31-40$} \\
\hline & $\begin{array}{l}\text { Preterm } \\
\text { birth }\end{array}$ & $\begin{array}{l}\text { Base } \\
\text { sample }\end{array}$ & $\begin{array}{l}\text { Preterm } \\
\text { birth }\end{array}$ & $\begin{array}{c}\text { Base } \\
\text { sample }\end{array}$ & $\begin{array}{l}\text { Preterm } \\
\text { birth }\end{array}$ & $\begin{array}{c}\text { Base } \\
\text { sample }\end{array}$ & $\begin{array}{l}\text { Preterm } \\
\text { birth }\end{array}$ & $\begin{array}{c}\text { Base } \\
\text { sample }\end{array}$ & $\begin{array}{l}\text { Preterm } \\
\text { birth }\end{array}$ & $\begin{array}{c}\text { Base } \\
\text { sample }\end{array}$ \\
\hline $0-1$ & - & 4 & 2 & 2 & 1 & - & - & - & - & - \\
\hline $1-10$ & 1 & 1 & 13 & 39 & - & 11 & - & 2 & - & 1 \\
\hline $11-20$ & - & - & 12 & 14 & 5 & 8 & 2 & $\overline{4}$ & - & 1 \\
\hline $21-30$ & - & - & - & - & 1 & 10 & 1 & 7 & - & - \\
\hline $31-40$ & - & - & 1 & 1 & 2 & 1 & $i$ & 4 & 3 & 3 \\
\hline
\end{tabular}

a Test of agreement between the differences in the statements of the women and the employers in the case group and base sample by Mann-Whitney's U-rank sum test $(P=0.68)$. [Light weight for delivery dates $(N=57), P=0.25$; low birthweight $(N=25)$, $P=0.09$; all deaths in the first year of life $(N=13), P=0.15$.

9), our studies do not support the hypothesis that VDT work in itself is a cause of adverse pregnancy outcomes.

\section{Acknowledgments}

We wish to thank Professor J Olsen, Dr KO Larsen, and Ms L Helsborg for their scientific assistance. In addition the technical, administrative, and practical support of Ms B Waldstroem, Ms L Nielsen, Ms AC Dam, and Ms A T Johansen, Ms J Klausen, Mr SE Hermansen, and the Union of Commercial and Clerical Employees in Denmark, and the performance of the telephone interviews by $\mathrm{Ms} \mathrm{H}$ Brandt, $\mathrm{Ms} \mathrm{H}$ Bräuner, Ms $\mathrm{K}$ Johansen, and Ms $\mathrm{H}$ Nicolaisen are gratefully acknowledged.

The study was financed by The Occupational Medical Research Fund in Aarhus, The Medical Research, Fund and The Health Fund.

\section{References}

1. Kurppa K, Holmberg PC, Rantala K, Nurminen T, Saxén L. Birth defects and exposure to video display terminals during pregnancy: a Finnish case-referent study. Scand J Work Environ Health 1985;11:353-6.

2. Ericson A, Källén B. An epidemiologic study of video screens and pregnancy outcome: I. a register study. Am $\mathrm{J}$ Ind Med 1986;9:441-57.

3. Ericson A, Källén B. An epidemiologic study of video screens and pregnancy outcome: II. a case-control study. Am J Ind Med 1986;9:459-75.
4. Nurminen T, Kurppa K. Office employment, work with video display terminals and course of pregnancy: reference mothers' experience from a Finnish case-referent study on birth defects. Scand J Work Environ Health $1988 ; 14: 293-8$

5. McDonald AD, McDonald JC, Armstrong B, Cherry $\mathrm{N}$, Nolin $\mathrm{AD}$, Robert D. Work with display units in pregnancy. Br J Ind Med 1988;45:509-15.

6. Goldhaber MK, Polen MR, Hiatt RA. The risk of miscarriage and birth defects among women who use visual display terminals during pregnancy. Am $J$ Ind Med 1988;13:695-706.

7. Bryant HE, Love EJ. Video display terminal use and spontaneous abortion risk. Int J Epidemiol 1989;18: $132-8$.

8. Nielsen CV, Brandt LPA. Spontaneous abortion among women using video display terminals. Scand J Work Environ Health $1990 ; 16: 323-8$.

9. Brandt LPA, Nielsen CV. Congenital malformations among children of women working with video display terminals. Scand J Work Environ Health 1990;16:329 33.

10. Miettinen OS. Theoretical epidemiology: principles of occurrence research medicine. New York, NY: John Wiley and Sons, 1985.

11. Greenland S. Adjustment of risk ratios in case-base studies (hybrid epidemiologic designs). Stat Med 1986; 5:579-84.

12. Butler WJ, Kalasinki LA. Statistical analysis of epidemiologic data of pregnancy outcomes. Environ Health Perspect 1989;79:223-7.

13. Kleinbaum DG, Kupper LL, Morgenstern H. Epidemiologic research: principles and quantitative methods. New York, NY: Lifetime Learning Publications 1982: 194-219.

Received for publication: 19 April 1991 